\title{
BRAZILIAN HOUSING BUBBLE: OVERPRICED HOMES, SUBPRIME CREDIT AND OVERWHELMING INCOME TRANSFER
}

\section{BOLHA IMOBILIÁRIA BRASILEIRA: CASAS CARAS, CRÉDITO SUBPRIME E ESMAGADORA TRANSFERÊNCIA DE RENDA}

\author{
Maria Paula Costa Bertran ${ }^{1}$ \\ lara Pereira Ribeiro
}

\author{
"I used to be poor. \\ Nowadays, I'm still poor \\ and I'm also in debt " \\ Anonymous Brazilian phrase. \\ "Eu era pobre: \\ Hoje em dia, ainda sou pobre \\ mas também estou endividado." \\ Frase brasileira anônima
}

\begin{abstract}
In Brazil, thousands of people have given all their savings to homes that will never be theirs. New residential buildings remain uninhabited in essential areas of Brazilian cities. This paper aims to show that intentional lack of austerity in the analysis of real estate financing has a critical responsibility for this scenario. The results of granting credit to people who could not afford it are contracts breached in impressive amounts and the recovery of properties given as collateral to banks in massive volumes.

This paper was structured on public data on real estate and household indebtedness, the specialized literature on management of construction companies, journalistic data on the breach of financing contracts and judicial decisions.

The results indicate that the supply of real estate financing for people who could not fulfill the contracts in the long term counted on at least three kinds of stimulus: high brokerage rates, promises of high returns to investors of real estate companies and the increasing prices of real estate, made possible by the undue credit offer.
\end{abstract}

Keywords: Real Estate; Credit; Breach of Contract; Collateral; Brazil.

\section{Resumo}

No Brasil, milhares de pessoas deram todas as suas economias investindo em casas que nunca serão suas. Novos edifícios residenciais permanecem desabitados em áreas essenciais das cidades brasileiras. Este artigo pretende mostrar que a falta intencional de austeridade na análise do financiamento imobiliário tem uma responsabilidade crítica por este cenário. Os

\footnotetext{
1 Professora Associada da Faculdade de Direito de Ribeirão Preto da Universidade de São Paulo. LivreDocente em Sociologia Jurídica pela Universidade de São Paulo. Doutora em Direito pela Universidade de São Paulo. E-mail: bertran@usp.br

2 Professora da Faculdade de Direito de Ribeirão Preto. Doutora em Direito Civil. E-mail: iararibeiro@usp.br
} 
resultados da concessão de crédito a pessoas que não podiam arcar com os custos são contratos violados em quantias impressionantes e a recuperação de propriedades dadas como garantia aos bancos em volumes maciços.

Este artigo foi estruturado com base em dados públicos sobre o setor imobiliário e endividamento das famílias, a literatura especializada sobre gestão de empresas de construção, dados jornalísticos sobre a quebra de contratos de financiamento e decisões judiciais.

Os resultados indicam que a oferta de financiamento imobiliário para pessoas que não conseguiam cumprir os contratos no longo prazo contava com pelo menos três tipos de estímulo: altas taxas de corretagem, promessas de altos retornos aos investidores das empresas imobiliárias e o aumento dos preços dos imóveis. imobiliário, possibilitado pela oferta de crédito indevida.

Palavras-chave: Imobiliário; Crédito; Quebra de Contrato; Colateral; Brasil.

\section{INTRODUCTION}

One in two properties sold has been "returned" to real estate companies in recent years in Brazil. (PASQUALIN, 2016, p.66). Parallel to the breakdown of contracts with the companies, there was a significant increase in the takeover of the properties given as collateral to the banks. It is estimated that the five most significant Brazilian banks have more properties (equivalent to $R \$ 10$ billion) than the stock of the most significant Brazilian real estate company (equal to R \$ 6.4 billion) (MANDI and PINHEIRO, 2017).

The economic crisis, unemployment, declining population income and recession are undoubtfully responsible for this scenario. But in addition to these quite uncontrollable factors, this article points out the lack of rigor in credit analysis was a determining criterion for installment contract breaches. Many individuals could not, by the traditionally expected standards, have started a long-term real estate financing. Between 2004 and 2014, at least three factors motivated a sloppy loan offer: promises to the capital markets investors, the rising of real estate futures prices, and the increased interest on brokerage commissions.

The offer of sloppy real estate credit structured a mechanism for transferring the total saving (and part of the income) of the individuals to the real estate companies and the banks, until around 2014. By 2014, it was the moment that the population had more savings and the higher incomes in the last four decades. Around 2014, a significant volume of real estate purchasers lost their jobs or reduced their salaries. In this scenario, real estate loans ceased to be repaid. When the population most needed credit, the real estate credit became scarce and much more expensive than it had been, just a short time before. From the population's point of 
view, there were two consequences: the loss of the acquisitive claim on real estate and the impossibility of recovering the amounts already paid.

If an acquirer fails to pay the installments of their real estate financing to the real estate companies, the agreement is settled. The real estate companies must return a percentage of the value the acquirer already paid, but not the whole amount. This is the first method of income transfer. If a bank sells a property that is sold at a fiduciary price for less than the one contracted initially, it will return to the original acquirer a lower value than the amount he has already paid. This is the second form of income transfer. This is not a negligible phenomenon, considering the number of breaches of contracts with the real estate companies and the number of foreclosures with the banks.

This article is organized into three parts. The first exposes the context of real estate financing in Brazil, based on the systematic creation of credit lines. The primary focus is on the traditional patterns of risk analysis and how it didn't fit Brazilian experience.

The second part explains the construction sector peculiar financial and contractual engineering. We elaborate the idea that real estate credit was granted out of the classically expected parameters because the fundamental guarantee against default was only the ephemeral wealth of Brazilians as a whole.

The third part questions what left over, for cities and citizens, after more than a decade of economic growth and income distribution? What do Brazilians have now, that they did not have in the early 2000s? The epigraph of this work suggests an answer.

\section{HISTORY OF BRAZILIAN REAL ESTATE}

The real estate can be acquired in cash, (in which case the acquirer has the money in advance), or in a piecemeal manner. As Brazil is a country with very poor income distribution, property purchases in cash are not uncommon but are usually intended for the homes of the rich.

There are two forms of real estate acquisition in installments (ELOY, 2014). The socalled Sistema Financeiro da Habitação (SFH), was created in 1964 and is characterized by state regulation of real estate financing conditions, including interest rates and terms. The resources that supply this system come from two sources: (i) a type of individual savings account (ii) and a mandatory fund sponsored by employers, to protect employees in case of dismissal, called the "Fundo de Garantia por Tempo de Serviço - FGTS ", which we call severance pay fund. Private 
banks may have access to savings accounts and the severance pay fund to broker real estate financing. Private banks have autonomy over some aspects of the contracts (especially on whom to offer or refuse credit), but they cannot freely determine all the clauses of these loans. In practical terms, federal government regulation makes this a subsidized type of financing, whose maximum and minimum interest rates vary, depending on household income and real estate value. The references to the SFH will from now on be referred to by the term "popular funding system". In this system are included the operations contracted with public resources that subsidize the contracts, according to the family income. SFH includes the famous "My Home, My Life Program" (CAIXA, 2017, page 3).

The so-called Sistema Financeiro Imobiliário (SFI), in turn, allows free negotiation between the parties, without regulation of the financing conditions. In this market system, the financing can be granted exclusively by banks or by a financing system partially granted by the constructors and partially granted by the banks (CAIXA, 2017, p.3). We will call it a "financially funded system."

Ideally, the real capacity of each household to contract housing financing would be defined by the financial agents. Financial agents should, therefore, consider the family spending profile, in both monthly expenses and other medium and long-term financial commitments. Agents should also check the stability of this income.

The monthly family expenses are usually declared by the family itself, but are checked through documents and financial records. This evaluation is not a trivial task from a methodological point of view, since the financial capacity varies according to the family composition (and the consequent per capita income), the cost of living in each region, the conditions under which credit is offered and real estate prices (ELOY, 2013, p.55). This individualized process of analysis results in the definition of the commitment of income to the benefit that can be borne by the family. This personalized analysis results in the qualification (or disqualification) of a person for given financing. This process integrates the credit risk intelligence of each agent and follows its models.

According to the law, the financial commitment must be compatible with family income: "The level of purchaser family commitment in operations under the SFH and the conditions of its verification will be fixed by the financial agent $[\ldots$ and ... the financing limits will be established by the financial agents according to the analysis of the capacity to pay "(BANCO CENTRAL DO BRASIL, 1980). 
Ideally, the design of the credit policy for housing financing, both in the subsidized model and in the market model, should require estimating the households' ability to afford housing and housing finance. In the same way, ideally, there should be a segmentation of the population for the different degrees of subsidies and the interest of different levels.

Despite the expected rationality of the credit analysis mechanisms, we understand that a significant part of the housing crisis in the real estate sector was due to suspect analysis procedures employed during the vetting of people's eligibility for credit. (BERTRAN-MUÑOZ, 2015).

\section{THE HOUSING FINANCE PROJECTS}

The structure of real estate sales over recent years in Brazil has had two outstanding characteristics. The first was that the real estate boom occurred with new real estate, built simultaneously with financing agreements. The second was that the commercial projects frequently involved a phase of financing directly with the constructors during the construction of the houses and a step of funding directly with the banks when the properties were ready to be inhabited.

In the first phase, the banks directly finance the real estate companies, so that they have the resources to construct the properties. In parallel, real estate companies begin to receive the funds of home buyers. The first phase lasts an average of 36 months and coincides with the time it takes buyers to pay about 30\% of the value of their homes. The 36-month "wall-building" period is not a technically necessary phase in engineering terms. In fact, the period of 36 months to complete the buildings corresponds to the average time required for the consumer to pay a minimum of about $30 \%$ of the final value of the apartment (ABRAINC, 2015).

\section{LAUNCH AND BUILD CYCLE}

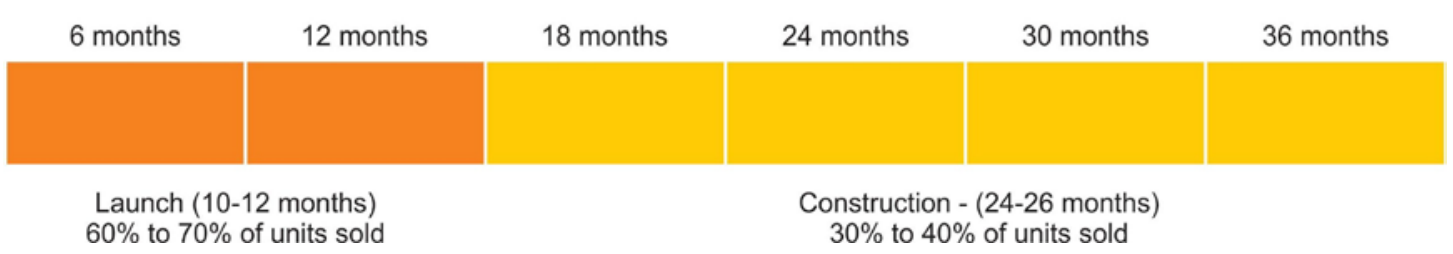

SOURCE: Brazilian Association of Real Estate Companies - Associação Brasileira de Incoporadoras ABRAINC, 2015, p. 11. Quoted as part of the study "The cost of bureaucracy in Brazil", conducted by Booz $\&$ Co. 
The second phase begins when the houses are ready, and the keys are delivered. At this time, via a new contract, the banks pay the full value of housing to real estate companies, which realize the profits on the housing and withdraw from the contractual relationship between the banks and the buyers. After the withdrawal of the real estate company, the ownership of the housing is transferred to the bank, without possession, in a kind of chattel mortgage. The acquirer loses possession if he delays the installments of the loan. Buyers are expected to be able to pay the rest of the property ( $70 \%$ remains to be paid) over an extended period that can range from 15 to 30 years. (ABRAINC, 2015)

\section{Business Steps and Investment Flows}

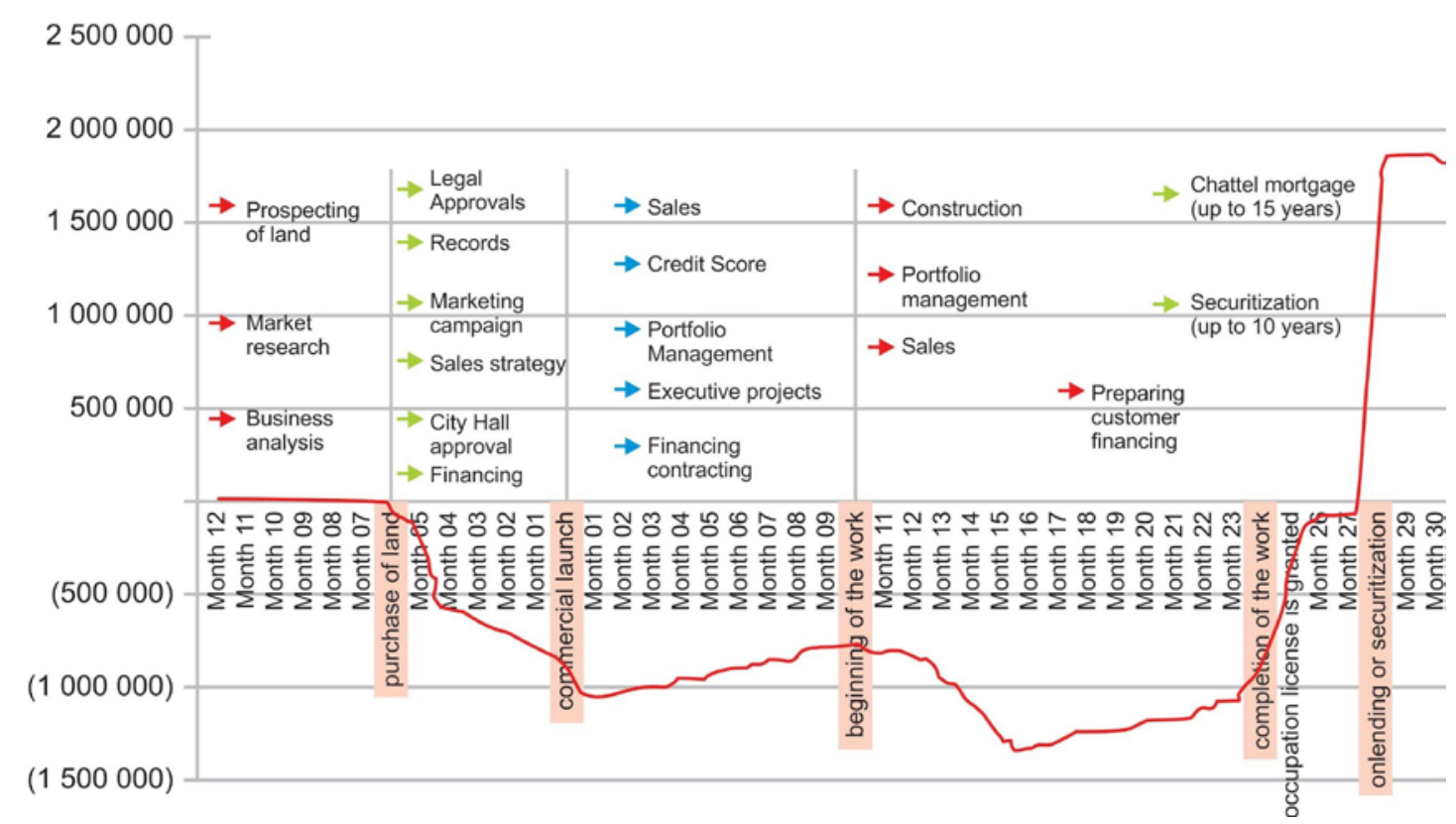

Source: Brazilian Association of Real Estate Companies - Associação Brasileira de Incoporadoras ABRAINC, 2015, p. 12.

Three reasons for a sloppy credit analysis: brokerage, image to the capital market and future price increase

The problems that will cause contract breaches begin early in the first phase of the financial project.

The commercialization of an apartment building or a group of houses can begin after the notarial record. At the time of the notarial document, the real estate developer publicly signs the type and characteristics of the property that it intends to build. From the notarial record, the real estate company launches its product and starts selling the houses with much 
advertising. It involves the exhibition of the building in various media, the use of promotional material, the presentation of models and floor plans in sales booths and the construction of spaces that simulate the apartments after they are built, beautifully decorated, "with the intention of instilling in the client the yearning for the property and for what it represents. " (ABRAINC, 2015)

The sale of the properties can happen through two types of agents: own sales team and outsourced sales team. The company's staff typically reflects specific training in negotiation, finance, and economics. The company's staff usually knows the particularities of the properties they are selling. Outsourced teams contribute with an overview of the real estate industry as a whole as they try to sell properties from various real estate companies. Outsourced teams bring information to customers about what is being offered by competing constructors and how competitors' products behave regarding prices and sales.

Sales services give rise to a commission of about $6 \%$ of the final value of the property. The professional sales approaches, stimulates, convinces, removes doubts and difficulties. The motivation for the sale of properties is not linked in any way to the ultimate success of the business. In other words, the commission is due, even the if the buyer never resides in the property or cannot pay the financing until the end of the installments. (PASQUALIN, 2016, p.35)

Brokers cannot decide alone on sales because real estate companies need to assess the creditworthiness of potential buyers. The real estate firm should theoretically evaluate whether or not the income documents of the interested parties would meet the company's security requirements. Ideally, real estate companies should assess the viability of the interested party for the security of the values that go directly to them, as well as for the protection of the costs that will later go to the banks.

Until 2014 there were two incentives for the analysis of credit records to be misleading and unwise (in addition to the $6 \%$ commission at the time of sale).

The first of these incentives was "to meet targets announced to the capital market, to make artificial balance sheet results." According to one of Brazil's leading real estate finance experts, "(...) the presence of speculative capital in the residential market of São Paulo [the largest city in Brazil] remained clear, as it was also clear that firms did not halt speculators to improve the quality of real estate market "(LIMA JR, 2014, 24).

One of the most significant Brazilian construction companies noticed a material fact for the capital market that exemplifies this argument. According to the text, published in many 
Brazilian newspapers (Folha de São Paulo, February 14, 2009, quoted by MARTINS, 2010, page 36)

"Cyrela Brazil Realty (...) announces to its shareholders and the market in general its projection of launches and contracted sales for the years 2011 and 2012 and ratifies projections of launches and sales contracted for the years 2009 and 2010 (...) "

\begin{tabular}{|c|c|c|c|c|}
\hline GUIDANCE & 2009 & 2010 & 2011 & 2012 \\
\hline Launches (BRL billions) & 4.6 to 5.1 & 6.9 to 7.7 & 8.3 to 9.1 & 10.5 to 11.5 \\
\hline $\begin{array}{c}\text { Sales } \\
\text { (BRL billions) }\end{array}$ & 4.6 to 5.1 & 6.2 to 6.9 & 7.6 to 8.4 & 9.7 to 10.7 \\
\hline
\end{tabular}

"(...) Also, the Company announces its gross margin, EBITDA margin and EBITDA margin for consolidated financial statements for 2009, 2010, 2011 and 2012, According to current accounting standards. "

\begin{tabular}{c|c|} 
Gross margin & $33 \%$ to $37 \%$ \\
\hline EBITDA income & $20 \%$ to $24 \%$ \\
\hline Net margin & $14 \%$ to $16 \%$ \\
\hline
\end{tabular}

Not surprisingly, irresponsible sales were encouraged to create a false showcase to hold (and attract more) international investments. The sales of real estate should respond to the production of the value of the capital given to the firms in advance, in an ever-increasing manner. It was necessary to think about (i) the present profits of real estate companies, (ii) the capital income advanced by the resource holders who invested in real estate companies, and (iii) the attraction of more investments to the sector. To account for the valuation and remuneration of incomes, the logic established in all stages of the real estate business was the logic of scale production. From construction sites to managers, from marketing to sales, all areas needed its continuous expansion. (Martins, 2010, 55)

The second incentive to make sales with sloppy analyses of buyers' financial capacity was that the higher the number of sales, the higher the price of properties. Speculative prices are defined as those that have a profit margin significantly higher than the one that can be inferred when it is possible to measure the "fair price" in a given market environment. The diagnosis made for Brazil is that the market environment made it possible to practice prices above the "fair price". This was caused both by imbalances in demand and by the dispersion of misperceptions about future housing prices.

Demand imbalances occurred because the sale of many properties was made to people who could never have obtained credit approval if usual due diligence standards had been 
applied. After 2014, the number of contract breaches multiplied because the enormous demand for properties took place on an artificial basis.

The dispersion of misperceptions about the future prices of housing has led to everincreasing prices. It was reported that the price per square meter for properties in Rio de Janeiro was more expensive than the prices of the most exclusive and charming addresses in the world. Besides the mistaken dispersion on prices, this was possible due to a temporary appreciation of the Brazilian currency. In this sense, it is interesting to translate a long, but elucidative newspaper article, published in 2011 (FREITAS, 2011).

According to real estate experts, the price per square meter of highstandard real estate on the edges of Leblon and Ipanema [two neighborhoods from Rio de Janeiro] can reach more than BRL 50,000 [equivalent to US\$25,000 at the time the news was written]: twice the value of the coveted regions of Miami and 30\% higher than those charged in Monaco. Compared to New York City, prices are compatible. (...)

About New York, real estate prices in Rio are becoming compatible. In Tribeca, a suburb of midtown Manhattan, the cost of the square meter ranges from US\$15,000 to US\$30,000, according to the survey. (...) In one of the most desirable areas of Miami, Sunny Isles Beach, the square meter costs about BRL 9 thousand [US \$4,500].

Meanwhile, in a central street of Leblon, near the beach, there is an offer of an apartment of 165 square meters, with four bedrooms and an ensuite master bedroom, for BRL 3.5 million. The price of the square meter, in this case, comes to BRL 21 thousand [US\$ 10.5 thousand], more than twice the cost of the apartment in Miami with a view of the sea.

In a recent trip to Monaco, [a real estate broker] noted that properties situated in prime areas, overlooking the Mediterranean Sea and with features similar to an apartment in Rio, could cost 30\% less. In Mallorca, Spain, [a realtor] found excellent properties, with vineyard and the Mediterranean Sea views for less than half the price of the apartments on the shores of Leblon and Ipanema (...)

In the evaluation of [another realtor], the rapid growth of prices in Rio, which reached $150 \%$ appreciation in two years, puts the city at the same level as the others, what was necessary for his opinion. '(...) Rio needed this valorization because its prices were detached from others occupying coveted areas. Rio is the coolest place in the world nowadays, due not only to its beauty and history but also to the upcoming Olympic Games. '"

The real estate valuation of Rio de Janeiro was more significant than the appreciation that occurred in the rest of Brazil. Among other reasons, because the average enrichment of the population of Rio de Janeiro was higher than the one seen in the rest of the country, mainly because of the discovery of new oil reserves and by the economic rush that preceded the 2016 Olympic Games. However, the insanity of Brazilian real estate as a whole made it possible that a Latin American middle-class apartment could cost more than a European castle. 
The graph below shows the growth, in nominal values, of 4 indexes:

a. Fipe-Zap - the index that compares the offer prices of real estate in 11 Brazilian metropolitan areas.

b. Ivg-r - Assured Residential Real Estate Asset Values Index - measures the long-term trend of residential real estate values in Brazil. The valuation of properties linked to real estate loans to individuals is used to calculate the guarantee of residential mortgage or chattel mortgage of properties in the main metropolitan areas.

c. Family income curve - serves to demonstrate that although it shows progress above the inflation curve, it is well below the residential real estate price curve.

d. IPCA-IBGE - the index that measures the inflation of products that meet the basic needs of Brazilian consumers, including expenses with food, transportation, housing, health and personal care, clothing, communication, education, etc.

FIPE-ZAP, IVG-R, FAMILY INCOME AND INFLATION INDEXES (adjusted for the same base - 100 - in January 2005)

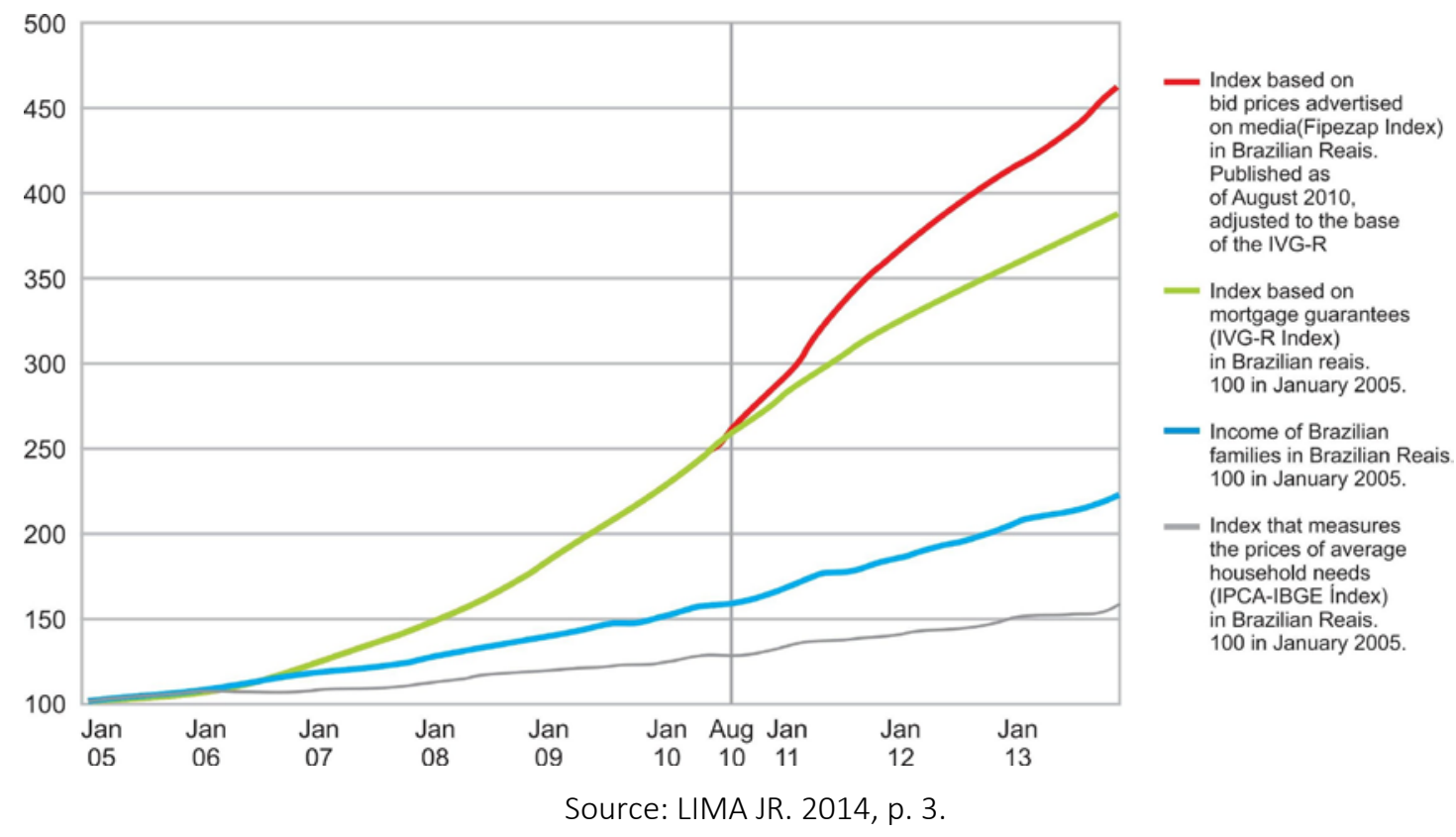

Lima Jr. starts the graphic representation in January 2005 because from this moment on; the real estate offer changed a lot in Brazil. This was the moment of the entry of significant amounts of foreign capital to Brazilian real estate companies. (LIMA, JR, 2014, p.5) 
A significant mismatch can be seen between the red/green lines and the blue/grey lines.

The red and green lines grew together until August 2010. From 2010 on, the red line increased more than the green line. The red line, FIPE-Zap Index, reflects the prices asked by owners and real estate companies. Those are not prices of effective sales, but it shows that people wanted to sell their real estate for more and more money. The red line demonstrates the dispersion of misperceptions about real estate prices. The green line, IVG-R, shows the effective prices of sales.

It is impressive to compare the top curves with the bottom curves. Population income (blue line) has grown above inflation (grey line), but both are far below the asking prices (red line) and the prices by which real estate was sold (green line).

In the context of the onset of the economic crisis, the diagnosis that real estate had appreciated well above inflation and people's income was removed from the argument that real estate-specific inflation index was much higher than the inflation indexes of primary consumer products. The products measured to determine the specific inflation of construction inputs (cement, iron, land, construction workforce, etc.) are in fact very different from the products weighed to determine average household consumption inflation. The grey line inflation was based on the price variation of food, transport, housing, health and personal care, clothing, communication, education, etc. This argument was widespread, aiming to deny the existence of a Brazilian housing bubble (LIMA JR, 2014, p.17).

After a few years denying a housing bubble, one can deduce that the whole productive chain for housing construction in Brazil was based on misreporting and contamination of speculative prices; not only estate companies charging more than their apartments were worth. The workers also asked for salaries higher than the "fair wage." Landowners demanded prices that were greater than the "fair price." Input manufacturers asked for more than the "fair price." It was not a "wage-price spiral", but a "price-price spiral".

After the economic crisis, the price spiral stopped. And backed away. In 2017, the real estate prices are equal to those from 2009. In the period between June 2014 and June 2016, there was an actual decrease of $29 \%$ in real estate prices, returning to levels close to those practiced in 2009 (ALMEIDA, 2016). 


\section{ASSURED RESIDENTIAL REAL ESTATE ASSET VALUES INDEX (IVG-R) From 2005 to 2016}

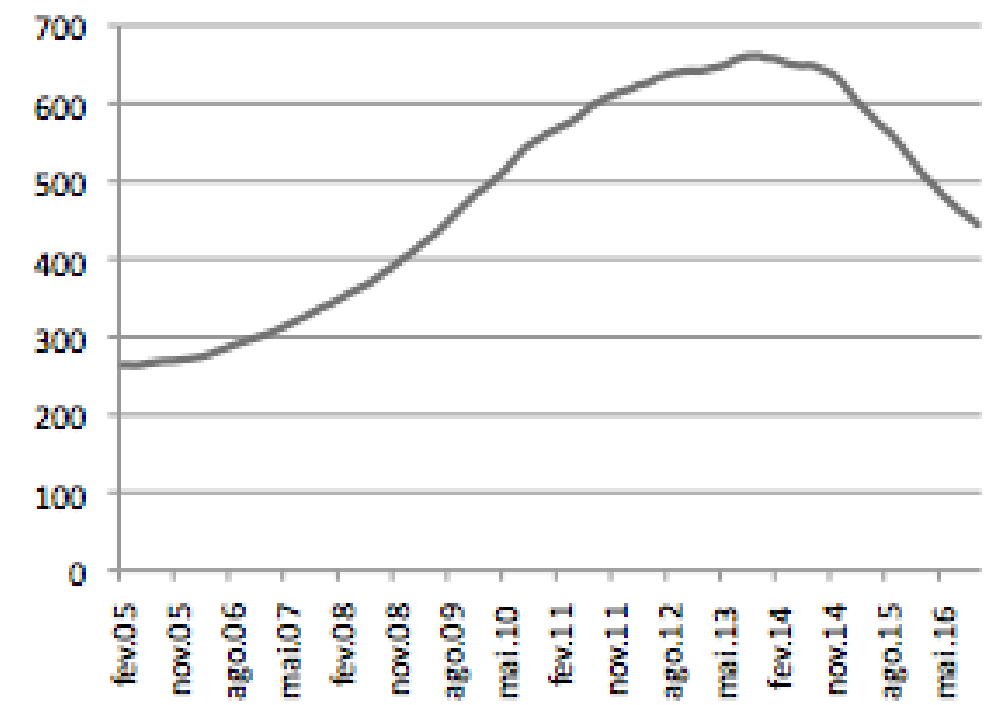

Source: The authors, with data from the Construction Trade Union - Sindicato da Construção SINDUSCON.

There are many justifications for the reduction of real estate prices. The first set of explanations, autonomous about market practices, includes i) the decline in people's income, ii) the reduction of people's confidence to take on long-term commitments, iii) fear of unemployment. The second set of explanations arises from the marks the behavior of the real estate companies printed even before the crisis: iv) the high number of breach of contracts (and consequently real estate devolution) increased companies' stocks; v) the feeling that the prices are still composed of speculative factors, even if they have reached 2009 levels.

\section{One reason to stop lending: earn more in another business (with less risk)}

The second phase of Brazil's real estate project finance is determining, today, a large part of the contract breaks. The second phase of typical real estate project finance begins when the housing nears completion and the keys are handed over. At this moment, the real estate company receives from the bank the amount still due and withdraws it from the contractual structure. The buyer no longer has the right to return the property to the construction company.

The property is transferred to the bank in a chattel mortgage form. The buyer is linked to the amounts contracted with the bank. The bank becomes the lender of the property for several years. If the debtor delays the payment of a monthly installment for 30 days (the market 
usually tolerates delays of 60 days), the property is immediately taken over by the bank. After the bank regains possession of the property, it is sold off.

In recent years, it is widespread for families to pay $30 \%$ of the value of the property to the construction company, nurture the expectation of moving to the new home (chosen up to 3 years earlier), prepare the move and present themselves to receive the keys. Just before the handover of keys, families find out that the bank loan was rejected, or approved in amounts lower than those required to finance the property.

A first diagnosis of the literature suggests that: i) the documents requested by real estate companies did not support the correct decision of real estate companies and ii) the credit rating made by the real estate companies did not take into account the same criteria adopted by the banks for the second phase of real estate financing. (PASQUALIN, 2016, p. 45) All the sources of this research suggest that this diagnosis is wrong.

The explanatory answer that comes to light from research sources is that in the anxiety to formalize many sales, real estate companies have established consciously irresponsible credit analysis criteria. The banks monitored this process of widening the concession of sloppy credit (BERTRAN-MUÑOZ, 2015). Both real estate companies and banks bet that the expansion of Brazilian income would be able to guarantee the flow of most of the financing. The problem only appeared when national wealth stopped flowing. (PAULA, 2017)

The opportunity to get out of this process was more manageable for banks than for real estate companies. The banks relied on i) the 3-year time lapse, the average time for housing construction, and ii) with better opportunities for gain in the traditional (and hugely profitable) system of Brazilian public debt securities.

Thus, in 2014, 2015 and 2016, as real estate companies struggled to maintain sales targets (and deepened their methods of lending credit), banks recognized the size of the economic crisis and repositioned themselves. At the same time, interest paid on Brazilian public debt securities grew from $7.5 \%$ per year (in 2013) to 14.25\% per year (in 2015) (BANCO CENTRAL DO BRASIL, 2017). The increase in interest paid on government bonds has once again attracted a traditional, safe, idle and passive form of gain to Brazilian banks.

At the moment, gains in scale due to controlled default have changed; the massive concession of credit to the population has ended. The loan guarantees were not the properties, but the context of economic growth. It was no longer safe to win by the expectation of gains in scale (many contracts) with a controlled default (low credit analysis rigor). In this new context, the defaults would be less predictable, implying real systemic risks. From this moment on, the 
credit given by the banks became scarce and more expensive both in the financial funding system and in the popular funding system. Although the popular funding system is regulated by the public sector, there is still room to increase interests. (QUINTÃO, 2017a)

\section{REAL ESTATE FINANCING INTEREST RATE (Average rate for individuals, \%)}

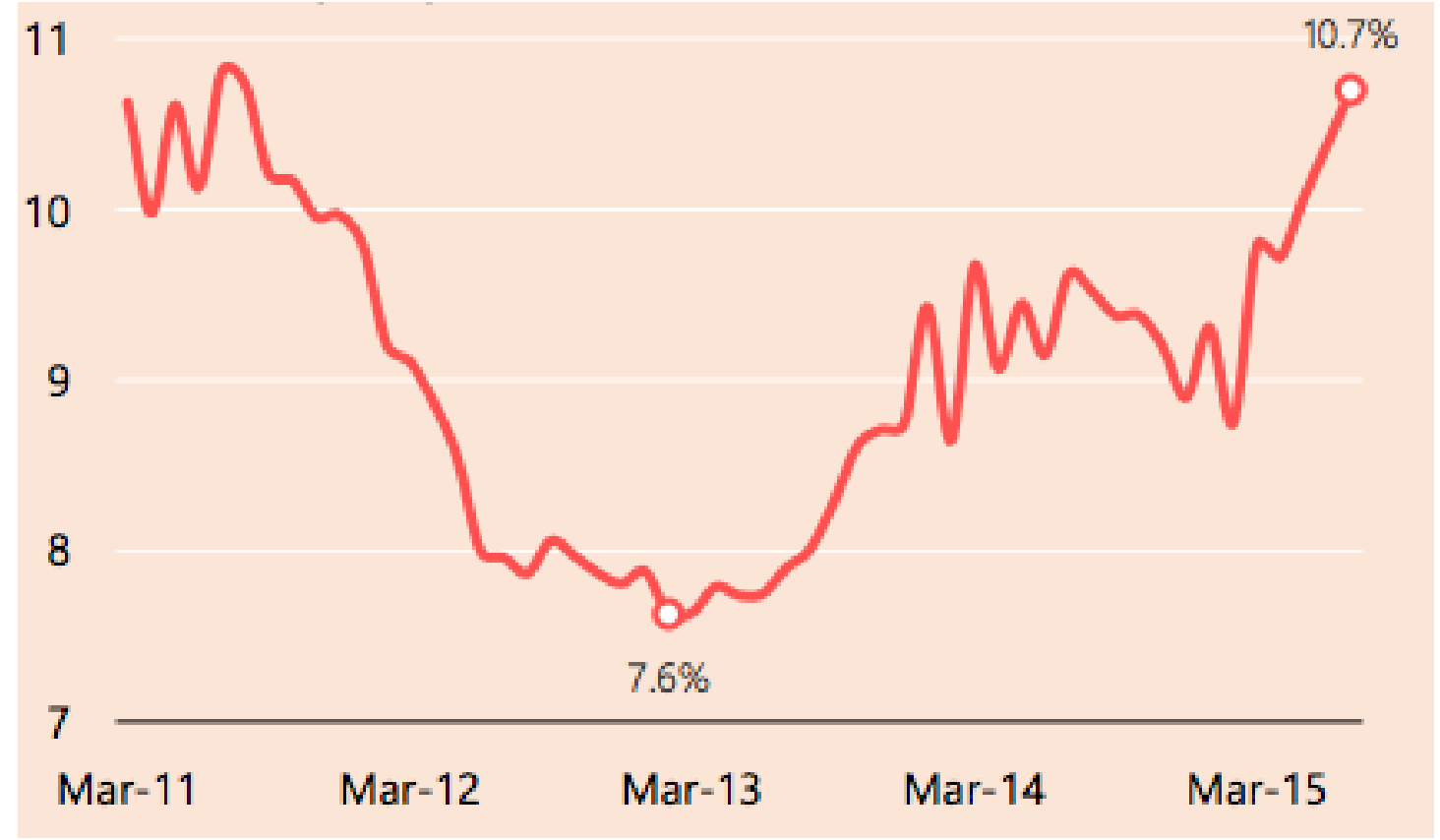

Source: FipeZap Newsletter \# 2 - September 2015. (FIPE ZAP, 2015).

The literature describes that "there is a combination of sharp shrinkage in the supply of credit (...) accompanied by greater selectivity (...) and a strong increase in bank spread (...)" (PAULA, 2017). "The commitment of family income to debt service increased from (...) 2005 to (...) 2015, in the context of a vigorous credit cycle, declining from the end of 2015 (...), which shows a gradual process of deleveraging in progress, in which families and companies postpone spending on consumption and investment."

The data indicate "(...) the permanence of an" overnight "circuit in the Brazilian economy (...) to which the high liquidity applications of economic agents are channeled (...), which compensate, at least partially, the losses in their revenues. In fact, the growth in the balances of (...) government bonds (...) plus the repurchase operations of the Central Bank of Brazil (transactions involving the purchase or sale of public securities with a commitment to resell or repurchase them at a future date) grew 55\% in real terms, from June 2014 to October 2016. Besides, gross public debt (...) grew from 52\% of GDP in April 2014 to $70.5 \%$ of GDP in November 2016 "(PAULA, 2017). Thus, the large banks - which account for about 90\% of the 
total assets of the sector - could maintain their high profitability in the midst of a massive economic crisis.

The absence of a destination for the resources previously used for the loans generated an excess of liquidity for the banks. This amount of resources has been redirected to investments in government bonds, whose high-interest rates have risen since the beginning of the crisis, at around $14 \%$ a year. This amount of money was also redirected to distribute profits among shareholders. It is worth noting that Brazilian banks belong to a handful of families (PINHEIRO, 2017).

"The explanation for the increase in dividend payments is simple: with the downturn in credit and large profits even in the context of a crisis, banks started working with 'idle capacity' on the balance sheet. Since they do not see opportunities to use these additional resources in the granting of financing, or in some big acquisition, the institutions have chosen to distribute this money to the shareholders "(PINHEIRO, 2017).

\section{SUMMARIZING THE BURSTING OF THE PROPERTY BUBBLE AND THE FALL IN REAL ESTATE PRICES}

People break contracts with real estate companies because: i) they have lost their jobs or suffered a decrease in income; li) did not get credit from the banks; or iii) their debts are much higher than the current real estate values. People fail to pay their installments to the banks for the reasons "i" and "iii" above.

During the real estate construction phase, at least three grounds for irresponsible credit can be cited: (i) gain of commissions on sales; (li) promises to the capital market and (iii) rising real estate prices.

The transfer of income from the population to the real estate companies appears in this scenario in three different ways: the loss of the amounts paid as commission, down payment fees and initial installments (up to $30 \%$ of the value of the property), and artificially high real estate prices.

When brought to courts, real estate companies are required to refund a considerable portion of the amount paid by buyers. There are variations depending on geographical location, but there is a consensus that judicial decisions need real estate companies to repay between $75 \%$ and $90 \%$ of the amounts paid. The $6 \%$ of the brokerage is almost never returned. (Pasqualin, 2016, p.18). 
In the view of the real estate companies, the retaining values (10\% to $25 \%$ of the total paid, plus the $6 \%$ of the brokerage) are too small. In their point of view, the low retaining values encourage consumers to be opportunist (Pasqualin, 2016, p.18). Also in the opinion of real estate companies, consumers want to dispose of real estate because it is worth less now than when they signed the financing contracts (and not because they lost their jobs or have no money) (QUINTÃO, 2017b).

According to consumers, the retaining values are too large, as real estate financing contracts in Brazil require a down payment of $30 \%$ of the total cost of the property, which is mostly the savings of families, and was based on overpriced contracts. A compelling argument is that real estate companies' earnings were so high until 2014 that very few have financial problems today, even with the large volume of contract breaches.

Banks and real estate firms have different contract regulations. The contracts with banks are similar to an all-or-nothing game. There is no possibility of cancellation of the financing, with the return of the amounts paid. The buyer must pay the installments or lose the real estate given as a guarantee. Banks must sell the property that has been pledged as collateral and meet their credit with the money from the sale. If the value of this sale exceeds the value of the debt, banks must return to the original buyers what they had already paid.

There is no guarantee that there will be any refund of the amount paid to the bank. Buyers have already spent at least $30 \%$ of the value of the real estate to obtain bank financing and usually have much to lose. The bank can sell the property for a price below the cost initially estimated. Considering that the rates of 2017 have regressed to the 2009 values, banks will indeed have to sell the real estate below its original valuation, lest it will remain unsold. The original buyer suffers a loss because he will receive a lower value than the amount already paid during the financing, or receive nothing at all.

One given example: a homebuyer who has already paid 100 out of 180 installments and can't keep up the payments because he has lost his job. If the property is sold for 120 , the bank will take 80 , and the defaulting buyer will receive a return of 40 , even though he paid 100 and lost the real estate.

Since 2014, the banks interrupted credit lines for the acquisition of real estate. The granting of credit to individuals in Brazil is historically determined by the absence or presence of better business opportunities. While financial institutions were profiting more from inflation, in the 1980s, for example, there was practically no real estate financing in the country. Today, when financial institutions profit more from the public debt securities than from the supply of 
credit, there is also a decrease in volumes of credit for real estate financing. The diagnosis of banking institutions in Brazil today, therefore, goes through the unique situation of a credit crunch, without prejudice to the banks. (PAULA, 2017).

Given this context, we can summarize the situation of the actors who participated in the Brazilian housing bubble as follows:

\section{Real estate companies}

- Expressive growth until 2014

- High profitability until 2014

- Contract breaks from 2014, including:

- Increase in real estate inventories (caused both by the return of real estate by the huge number of breached contracts, and by the decrease in the pace of sales)

- Decrease in real estate prices

- Loss of value in the stock market from 2014 until nowadays

- Withdrawal of international investments from 2014 until nowadays

- The bankruptcy of some real estate companies (few, including the famous companies PDG and Viver).

Banks
- Expressive growth until 2014
- Maintenance of growth, but at a slower pace, from 2014 until nowadays
- Reduction of real estate credit
- Increase of interest for real estate lending
- Increase in repossession procedures to recover collateral
- Need to sell the properties given as guarantee

\begin{tabular}{|l|}
\hline \multicolumn{1}{|c|}{ Consumers } \\
\hline - Easy access to credit until 2014 \\
- Increase in income until 2014 \\
- Indebtedness above income capacity \\
- Inability to pay debts from 2014 to nowadays \\
- Devaluation of real estate from 2014 to nowadays \\
- Unilateral breach of contracts with real estate companies \\
- Default in bank loans and loss of collateral
\end{tabular}

Government

- Encouraged population indebtedness until 2014

- Income distribution policies until 2014 (some remain)

- Absence of maximum limits for credit card and real estate (non-subsidised) interests

- Absence of regulating real estate breaches of contract

- Passivity before the transfer of income from the debt, until the measures taken in 2017

- Use of the popular funding system for high-income real estate financing as a way to reduce unemployment 


\section{CONCLUSION: THE LOSS OF ANOTHER OPPORTUNITY IN THE LONG CURSE OF POVERTY}

The epigraph of this work ("I used to be poor. Nowadays I'm still poor and I'm also in debt") says a lot about the melancholic end of the Brazilian dream of growth, income distribution and decent housing for most of the people. The great life-enhancing opportunity of the last few decades has been lost in a plot that includes ambition, ignorance, lack of rationality and maintenance of the good of some by the sacrifice of many.

The real estate companies were greedy enough to attract the resources that turned Brazil into a vast construction site. Real estate expansion demanded a continuous inflow of funds. Unrealistic prices determined financing that may never be reverted. Real estate prices were determined by the delirium of perpetual economic growth. Banks have captured the unprecedented wealth of the population. As the opportunities for profiting from the indebtedness of the population ended, banks turned their attention to other investment opportunities.

Thousands of people have lost their entire life-savings to homes that will never be theirs. Thousands of people have earned well for the first time in their lives, and with this money, they have bought trinkets that will not help them to have a better life. Thousands of people today own a home but suffer the consequences of a poor-quality construction model, made with materials that are unsuitable for the climate and whose location makes them waste time and money for transportation. (The latter theme was not discussed in this work, but also contributes to the plot of the Brazilian real estate story.)

The resources of the real estate financing counted much more on popular funding than on financial funding. The market has organized itself to win with the real estate, but not to finance the real estate. The government chose debt as a form of economic growth but did not predict that the market would require such high counterparts. When debt numbers exposed the reality of income transfer, government reaction was slow and geared much more to the composition of interests than to the limitation of interest rates.

The characteristics of the Brazilian real estate bubble allow comparisons with similar phenomena around the world. Just as in the crisis of 2008 in the United States, the decrease of the income of the population was the trigger that triggered the process of falling prices. Unlike its predecessor, the Brazilian crisis did not reached the foundations of the financial system. 


\section{REFERENCES}

ANDRADE, André Pino da Silva. Avaliação recente da expansão do crédito no Brasil: boom ou crescimento sustentável? Dissertação de Mestrado. Faculdade de Economia, Contabilidade e Administração da Universidade de São Paulo. São Paulo, 2012.

ARAGÃO, Thêmis Amorim; ARAUJO, Flávia de Sousa; Adauto Lucio Cardoso. Habitação de Interesse Social: Política ou Mercado? Reflexos sobre a Construção do Espaço Metropolitano. XIV Encontro Nacional da ANPUR., 2011, p. 2. Disponível em: < http://www.observatoriodasmetropoles.net/download/adauto_cardoso.pdf

ANEFAC - Associação Nacional dos Executivos de Finanças, Administração e Contabilidade. Pesquisa de juros 2013. https://www.anefac.com.br/uploads/arquivos/2013111411130713.pdf

AGUIAR, José. Cadernetas de poupança e o financiamento imobiliário. Revista Construção e Mercado. Julho de 2015.

ALMEIDA, Natália Soares de Matos Almeida. Riscos relacionados ao real estate residencial e o processo de investimento adotado pelos parceiros-investidores como resposta. MBA Real Estate Poli. 2016.

BERTRAN, Maria Paula. Caros enganos: entre o discurso da confiança e a intenção da inadimplência. Tese de Livre-Docência. Faculdade de Direito de Ribeirão Preto da Universidade de São Paulo, 2015.

Justiça e Contrato: entre comutar e distribuir. São Paulo, Edusp, 2015.

BERGER, Allen N.; DE YOUNG, Robert. "Problem loans and cost efficiency in commercial banks," Journal of Banking \& Finance, vol. 21(6), Jun, 1997.

BRASIL. MINISTÉRIO DA FAZENDA. Economia Brasileira em Perspectiva. 2010. Disponível em: http://www.fazenda.gov.br/portugues/docs/perspectiva-economia-

brasileira/edicoes/Economia-Brasileira-Em-Perpectiva-Especial-10.pdf. Acessado em 08 set 2012.

BANCO CENTRAL DO BRASIL, 1980. Art. 11 da Resolução do Banco Central do Brasil 1980/1993 + Art. 21 da Resolução CCFGTS 702/2012, disponível em www.fgts.gov.br

CAMPOS, Eduardo e RIBEIRO, Alex. Crédito encarece apesar de corte maior na SELIC. Valor. 24 de fevereiro de 2017.

CAIXA 2017. Cartilha do Crédito Imobiliário. http://www.caixa.gov.br/Downloads/habitacaodocumentos-gerais/Cartilha_Credito_Imobiliario.pdf

ELOY, Claudia. Muda o governo, seguem os equívocos. Valor. 14 de fevereiro de 2017.

FIPEZAP Boletim Boletim FipeZap \#2 - Setembro de 2015. (FIPE ZAP, 2015). http://fipezap.zapimoveis.com.br/wp-content/uploads/2016/08/boletim-mensal-setembro.pdf 
FREITAS, Ystatille. Os preços de imóveis no Rio e em grandes cidades mundo afora. O Globo. 11 de novembro de 2011.

GOBETTI, Sérgio Wulff e ORAIR, Rodrigo Octávio. Progressividade tributária: a agenda negligenciada. Intituto de Pesquisas Econômicas Aplicadas. Texto para discussão. 2190. Rio de Janeiro, abril de 2016.

IBGE - Instituto Nacional de Geografia e Estatístiica - Tabela da pesquisa mensal de emprego, 2017. http://www.ibge.gov.br/home/estatistica/indicadores/trabalhoerendimento/pme_nova/

KOUTSOMANOLI-FILIPPAKI, Anastasia; MAMATZAKIS, Emmanuel, 2009. Performance and Merton-type default risk of listed banks in the EU: A panel VAR approach. Journal of Banking \& Finance, vol. 33(11), Nov, 2009

KOUTSOMANOLI-FILIPPAKI, Anastasia; MAMATZAKIS, Emmanuel, 2009. Performance and Merton-type default risk of listed banks in the EU: A panel VAR approach. Journal of Banking \& Finance, vol. 33(11), Nov, 2009.

MANDI, Carolina e PINHEIRO, Vinícius. Bancos têm 10 bilhões em imóveis retomados. Valor. 06 de março de 2017.

MARTINS, Flávia Elaine da Silva. A (re)produção social da escala metropolitana: um estudo sobre a abertura de capitais nas incorporadoras e sobre o endividamento imobiliário urbano em São Paulo. Tese de Doutorado em Geografia. Faculdade de Filosofia, Letras e Ciências Humanas na Universidade de São Paulo, 2010.

MEDEIROS, Marcelo; SOUZA, Pedro Herculano Guimarães Ferreira; CASTRO, Fábio Ávila The stability of income inequality in Brasil, 2006-2012: an estimate using income tax data and household surveys. Ciência e Saúde Coletiva, 2015., vol. 20, número 4.

MENDONÇA, Mario Jorge Cardoso. O crédito imobiliário no Brasil e sua relação com a política monetária. Revista Brasileira de Economia.Vol.67, número 4. Rio de Janeiro Oct./Dec. 2013

MINISTÉRIO DA FAZENDA. Relatório da Distribuição Pessoal da Renda e da Riqueza da População Brasileira: Dados IRPF 2015/2014. Maio de 2016. Disponível on-line em http://www.spe.fazenda.gov.br/noticias/distribuicao-pessoal-da-renda-e-da-riqueza-dapopulacao-brasileira/relatorio-distribuicao-da-renda-2016-05-09.pdf

MOTA, Camila Veras. Desemprego na Grande São Paulo bate recorde e atinge 16,8\%. Valor. 27 de janeiro de 2017

PAULA, Luiz Fernando. Porque a grande crise não aconteceu. Valor. 10 de janeiro de 2017.

PINHEIRO, Vinícus. Bancos privados elevam pagamento de dividendos. Valor. 13 de marco de 2017.

QUINTÃO, Chiara. Comprador tem de perder tudo em distrato, diz Cyrela. Valor. 3 de fevereiro de 2017. (2017a) 
QUINTÃO, Chiara. CBCl afirma que, sem regras para distratos, obras podem atrasar. Valor. 10 de fevereiro de 2017. (2017b)

ROYER, L. Financeirização da Política Habitacional: limites e perspectivas, 2009. Tese (Doutorado em Arquitetura e Urganismo) - Universidade de São Paulo, São Paulo, 2009.

TABAK, Benjamin M.; CRAVEIRO, Giovana L.; CAJUEIRO, Daniel O. Eficiência Bancária e Inadimplência: testes de Causalidade. Brasília: Banco Central do Brasil. Trabalhos para Discussão número 220, out. 2010, p. 4.

VETTORAZZO, Lucas e PERRIN, Fernanda. População brasileira empobrece 9,1\% com recessão econômica no país. Folha de São Paulo, 2017. http://www1.folha.uol.com.br/mercado/2017/03/1864296-populacao-brasileira-empobrece91-com-recessao.shtml

UQBAR. Anuário 2017 - Securitização e financiamento imobiliário. http://www.uqbar.com.br/institucional/oque/anuarios.jsp.

Trabalho enviado em 01 de março de 2018.

Aceito em 25 de março de 2018. 